\title{
Lealtad y unidad en Miguel de Lastarria y Francisco Magariños. Dos proyectos políticos para el Río de la Plata entre la restauración y el trienio liberal ${ }^{1}$
}

\author{
Ivana Frasquet ${ }^{2}$
}

Recibido: 23 de junio de 2020 / Aceptado: 21 de septiembre de 2020

Resumen. En este trabajo se pretende un abordaje de lo político desde dos experiencias vitales en las que impactaron las revoluciones de independencia durante los años de la restauración y el trienio liberal. Se trata de dos personajes, Miguel de Lastarria y Francisco Magariños, cuyas vivencias en el marco revolucionario del Río de la Plata impactaron sus horizontes de expectativas y configuraron sus identidades a través de unas posiciones de defensa y lealtad a la monarquía hispánica. En ambos casos, la línea que definió sus posicionamientos políticos ante la crisis monárquica fue la de una postura de absoluta fidelidad a la monarquía, pero que se tradujo en proyectos políticos distintos como solución al conflicto. El análisis de estos proyectos, en el contexto cambiante de la coyuntura revolucionaria a inicios del siglo XIX, permite observar las transferencias culturales y las readaptaciones y modificaciones de unas conductas que, lejos de ser incoherentes, se inscribieron en la lógica de la lealtad como eje primordial para ofrecer una salida adecuada a los conflictos producidos por las independencias.

Palabras clave: Lealtad; unidad; Monarquía; Trienio Liberal; Río de la Plata; siglo XIX.

\section{[en] Loyalty and Unity in Miguel de Lastarria and Francisco Magariños. Two} Political Projects for the Río de la Plata between Restoration and the Liberal Triennium

Abstract. The aim of this paper is to approach the political scenario from the perspective of two life experiences that were influenced by the independence revolutions during the years of the Restoration and the Liberal Triennium. Reference is made to two figures, Miguel de Lastarria and Francisco Magariños, whose experiences in the revolutionary context of the Río de La Plata influenced their horizons of expectation and shaped their identities through positions of defense of, and loyalty to the Hispanic monarchy. In both cases, faced with a monarchical crisis, their political positions were defined by a stance of absolute loyalty to the monarchy, but translated into different political projects as solutions to the conflict. The analysis of these projects, in the changing context of the revolutionary situation at the beginning of the 19th century, allows us to observe the cultural transfers and the readjustments and modifications of behavior which, far from being incoherent, were inscribed in the logic of loyalty as a primary axis toward an adequate solution to the conflicts produced by the independence movements.

Keywords: Loyalty; Unity; Monarchy; Liberal Triennium; Río de la Plata; 19th Century.

\footnotetext{
1 Este artículo se inscribe en el proyecto financiado por MINECO, "Entre dos mundos. Historia parlamentaria y culturas políticas en los años del Trienio Liberal (1820-1823)" (HAR2016-78769P).

2 Universitat de Valencia (España).

E-mail: Ivana.frasquet@uv.es
} 
Sumario. 1. Introducción. 2. Hacia la pacificación del Plata. 3. La política conciliatoria en el Trienio Liberal. 4. Lealtad y fidelidad en Francisco de Borja Magariños. 5. A modo de conclusión. 6. Referencias bibliográficas.

Cómo citar: Frasquet, I. (2021) "Lealtad y unidad en Miguel de Lastarria y Francisco Magariños. Dos proyectos políticos para el Río de la Plata entre la restauración y el trienio liberal", en Revista Complutense de Historia de América 47, 43-65.

América es un coloso que camina con firmeza hacia su independencia, sin que haya sobre la tierra poder humano capaz de contenerle en su marcha tan impetuosa como irresistible. Miguel Cabrera de Nevares ${ }^{3}$

\section{Introducción}

Desde que Fernando VII regresara al trono en 1814, y casi hasta su fallecimiento en 1833, no cejó en su empeño por recuperar sus antiguas posesiones americanas. La idea de la pérdida del imperio le resultaba ciertamente inconcebible, razón por la cual nunca abandonó la esperanza de la reconquista. Prueba de ello es que, todavía en diciembre de 1829 -y después de fracasada la última expedición enviada a México al mando de Isidro Barradas-durante la celebración del matrimonio con la que sería su última esposa, María Cristina de Borbón-Dos Sicilias, se erigió un templete en la Puerta del Sol de Madrid cuyas alegorías simbólicas representaban la conquista de América, con un globo terrestre del continente americano donde se podía leer la leyenda: "Todos españoles"4. La intransigente postura a no reconocer la evidencia llevaba a algunos, como Mariano Torrente, a afirmar obstinadamente que, en 1830, todavía existía en América una opinión favorable al monarca que haría culminar con éxito una empresa de reconquista. Como indicaba el diplomático y se asentaría en el relato político del liberalismo, tanto progresista como moderado, en los siguientes decenios: América se había perdido contra la voluntad de la misma América ${ }^{5}$.

En ese espacio que medió entre el regreso de Fernando VII y la vuelta al sistema constitucional, en el intervalo 1820-1823, fueron muchos los proyectos de reconquista que se diseñaron en los marcos de una política de pacificación que resultó de todo punto inflexible y anacrónica. Si, por un lado, durante la restauración fernandina se priorizaron las soluciones militares paralelas a las negociaciones diplomáticas; por otro, en la etapa liberal, se optó por un encaje constitucional que, casi a la fuerza, conminaba a los americanos a elegir entre la constitución o la independencia. La esperanza que muchos liberales americanos y peninsulares depositaron en el nuevo régimen inaugurado a partir de 1820 se frustró tempranamente al comprender que la independencia no iba a ser reconocida bajo ningún concepto por muy constitucional que fuera la monarquía.

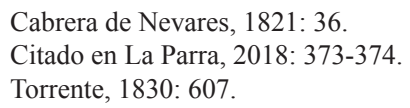


Los planes, proyectos, memorias, informes y anotaciones sobre el modo de recuperar los territorios americanos para la monarquía española que se elaboraron entre 1814 y 1830 son tan abundantes que sería imposible dar cuenta de todos ellos en un trabajo de esta extensión. Ello obliga a enfocar el propósito de las páginas que siguen en algunas de las propuestas referidas al territorio del Río de la Plata y a centrar fundamentalmente dos de ellas que reflejan posiciones distintas, pero no divergentes. Ambas parten de una misma postura de lealtad y fidelidad a la monarquía ${ }^{6}$, pero están trazadas por dos personalidades cuya experiencia vital será impactada de diversa forma por la revolución. Por un lado, Miguel José de Lastarria, funcionario ilustrado de la corona que pondrá sus amplios conocimientos al servicio de la causa de la reconquista y basculará entre posicionamientos reformistas y conservadores. Por otro, Francisco de Borja Magariños, perteneciente a la elite comercial montevideana y educado en un ambiente liberal de fidelidad y lealtad que abogará abiertamente por un desenlace peculiar para los territorios del Plata. Ambos pertenecieron a ese grupo de españoles americanos que, por encima de todo, preservaron la legitimidad de la monarquía y resguardaron la unidad a España como un mecanismo de supervivencia. Las diferencias generacionales les decantan hacia posturas más o menos liberales, pero igualmente leales en el seísmo que provocaron las revoluciones.

Es en este período de continuos cambios revolucionarios donde se pueden rastrear las aspiraciones políticas de los actores, sus redefiniciones ideológicas e identitarias y la comprensión de sus acciones en el marco de lo político como parte de sus prácticas y representaciones. Se trata, por tanto, de atender a la política no sólo desde lo institucional sino también desde la reconstrucción de los actos personales como cauce de desarrollo de horizontes de expectativas y transferencias culturales que sirvieron para readaptar, resistirse o modificar los espacios políticos de actuación 7 . En las trayectorias vitales de estos personajes se puede reconstruir una parte de ese universo político permeado por posiciones indefinidas y cambiantes que tuvieron como eje primordial la unidad a la monarquía y la lealtad al rey.

\section{Hacia la pacificación del Plata}

Nada más recomponer su gabinete ministerial en 1814, el rey atendió el asunto americano con cierta celeridad. Sin duda, el refuerzo de las monarquías europeas tras la desaparición definitiva de Bonaparte, facilitaría su postura oficial, basada en razones de justicia, para recuperar los territorios americanos. Como era sabido, el principio de legitimidad no se circunscribía únicamente a la subsistencia de las coronas en sus tronos europeos, sino también a la integridad del territorio bajo el dominio de las mismas ${ }^{8}$. Por esa razón, la monarquía española buscó obtener la aquiescencia de las potencias europeas, principalmente de Gran Bretaña, para iniciar una estrategia de restablecimiento de sus derechos americanos que simultaneaba diferentes vías entre las que se encontraban, fundamentalmente, la diplomática y la militar.

6 Partimos del planteamiento que realizó Ana Ribeiro al analizar la lealtad al monarca como el rasgo definitorio y más persistente de todos los que presentaron los leales. Ribeiro, 2013, t. II: 303.

7 La idea de un "horizonte de expectativas" y un "espacio de experiencia" se plantea metodológicamente desde los trabajos de Koselleck: 1993; pero también desde la experiencia hermenéutica contenida en Jauss: 1986, adaptada desde los planteamientos literarios de este autor a un contexto de tiempo histórico.

8 Molina de Muñoz, 1976: 59. 
La primera actuación de Fernando fue formar una junta el 3 de diciembre de 1815 para establecer los procedimientos a seguir en la reposición de sus dominios. Poco después, en mayo de 1816 consultaría sobre la conveniencia de reformular el sistema de comercio como remedio más eficaz para "aquietar y conservar" las regiones americanas rebeldes y obtener, de paso, la anuencia británica a su plan de restauración de sus posesiones. Ante la lentitud del avance de las resoluciones, el 7 de septiembre de 1816 ordenó crear otra junta y, finalmente, fusionaría ambas en la que sería conocida como "Junta de Pacificación" ". Desde entonces, el asunto de "la pacificación de las Américas" así, tan paternalista y eufemísticamente nombrado, ocupará buena parte de los dictámenes de los órganos consultivos del monarca, tanto en los años de absolutismo como durante el trienio liberal.

Como secretario de la Junta de Pacificación Fernando VII nombró a Miguel José de Lastarria, un ilustrado nacido en Arequipa que había ocupado diversos cargos administrativos en el virreinato del Río de la Plata, entre ellos el de fiscal de la real audiencia de Buenos Aires, y cuyos escritos y memorias sobre el estado y la organización de aquellos territorios podían resultar de interés para el caso. Lastarria era buen conocedor de los problemas que aquejaban al virreinato rioplatense, en especial, de los conflictos mantenidos en la frontera oriental del río con los portugueses. Llegó a la Península en 1803 para seguir un juicio y participó, a petición del entonces monarca Carlos IV, de la junta de generales consultiva de fortificaciones y defensa de Indias. Escribió entonces un manuscrito en tres volúmenes sobre la reorganización y la seguridad de los territorios orientales del Río de la Plata en donde, entre otras cosas, exhortaba a la corona para fortificar las fronteras con Brasil ${ }^{10}$. Elaboró también una carta geográfica y otra corográfica del "virreinato de Buenos Aires" y una memoria sobre el sistema de la real hacienda con relación a sus fuerzas militares. Sus trabajos quedaron en manos de la regencia y la secretaría de las Cortes durante el período en que estas estuvieron reunidas en Cádiz y un extracto de su "Memoria cronológica" fue publicado en París a partir del original que se llevó "el tirano Murat" de la biblioteca de Godoy, quien se había quedado el ejemplar porque le interesaba mucho ${ }^{11}$.

Poco después, Lastarria redactó un apéndice a la memoria en el que ya daba cuenta de la ampliación de territorio que Portugal estaba realizando ilegítimamente en la frontera sur de Brasil. Pensó que podía servir para tomar medidas preparatorias para la recuperación de las tierras ocupadas por los portugueses y como medio para contrarrestar "la funesta insurrección" de las provincias limítrofes del Río de la Plata"2. Estos trabajos habían sido consultados por el ministro Lardizábal en noviembre de

9 Por orden de Fernando VII de 26 de octubre de 1816 esta junta reunida la formarían el presidente del Consejo de Indias, duque de Montemar y los ministros del mismo consejo José Pablo Valiente, Francisco Arango y Manuel de la Bodega; a ellos se unieron los de la primera junta: Francisco de Requena, Antonio Gamir, Francisco José Viaña, Juan Gualberto González y Antonio Gómez Calderón; como secretario fungiría Miguel de Lastarria. Resolución de la junta de pacificación y consejo reunidos. Madrid, 8-II-1817. Archivo General de Indias [España] (en adelante AGI), Estado, 88, $\mathrm{n}^{\circ} 11$ (2).

10 Donoso, 1958; Cáceres, 2018; Martínez Martín, 2012. El trabajo llevaba por título Reorganización y plan de seguridad exterior de las muy interesantes colonias orientales del Rio Paraguai o de la Plata. 3 tomos, por Miguel de Lastarria, fiscal de aquella Real audiencia pretorial. 16 enero 1806.

11 Apunte de Papeles de Lastarria. Madrid, 26-XII-1818. AGI, Estado, 78, nº 47 (1a). Memoria que preliminarmente recuerda las ocasiones y fundamentos del sistema de Real Hacienda en el virreinato de Buenos Aires con relación a sus fuerzas militares: el estado progresivo de estas (en los siglos 17, 18 y 19), sus asignaciones, $\&^{a} \&^{a}$.

12 Río de la Plata de la Real Corona de Castilla hasta los términos del Tratado subsistente de 11 de octubre de 1777. 2 tomos, encuadernados a la holandesa y dorados. AGI, Estado, 87, nº 36. 
1814 cuando se preparaba la primera expedición para la reconquista. Lastarria fue comisionado entonces, por sus conocimientos sobre el virreinato rioplatense, para los preparativos de "la expedición de diez mil hombres al Río de la Plata, con el general D. Pablo Morillo, cuyo destino varió a la Costa firme"13.

En mayo de 1816 Lastarria fue requerido a instancias del rey para enviar sus dos volúmenes del apéndice sobre el asunto que por aquel entonces más preocupaba a la corona: la actuación de los portugueses en la Banda Oriental. Fernando VII quería saber si los aprestos militares que los portugueses habían estado realizando en la frontera sur eran verdaderamente hostiles. No en vano se había comprometido -por partida doble- a unir ambas coronas con los matrimonios de dos de las hijas de su hermana Carlota Joaquina, María Isabel con él y María Francisca con su hermano Carlos $^{14}$. A pesar de todo, parece que sus advertencias sobre la urgencia de "rescatar" los territorios del Río de la Plata cayeron en saco roto, ya que, poco después, la primera junta que formó el rey se inclinó por no tomar ninguna resolución hasta que no se formase el ministerio universal de Indias que debía encargarse exclusivamente del asunto de la pacificación americana.

Finalmente, el dictamen de la Junta de Pacificación, de la que Lastarria era secretario, fue evacuado el 8 de febrero de $1817^{15}$. En sus antecedentes se apuntaba al "actual sistema de comercio" como causa que mantenía a los habitantes del Plata en "perpetuo disgusto" y por el que se negaban a observar la ley. La junta fijó como de mayor interés el tema del comercio pues consideraba que en él se encontraba la llave para atajar la rebelión americana. En su resolución apuntó que, a modo de ensayo, debía variarse el sistema legal de intercambio y acomodarlo a conveniencia hasta que "se apacigüen los movimientos". De este modo se ganaría tiempo para preparar la reforma radical y perpetua que debía realizarse en el comercio colonial y que, sin ninguna duda, debía ampliarse a los extranjeros, de manera provisional. Seguramente no era el dictamen que Fernando VII quería escuchar, pero después de que los portugueses invadieran en 1816 sus posesiones en la Banda Oriental, no parecía quedarle otra opción que solicitar la mediación británica para contener los avances lusos en América del Sur. Si la intromisión de las potencias europeas en los asuntos americanos era inevitable, esta se focalizaría en Gran Bretaña, por un tiempo limitado y bajo ciertas reglas. La junta entendía que los británicos serían los más beneficiados con la liberalización del comercio y por ello ayudarían a que se conservara la paz. $\mathrm{Al}$ fin y al cabo, "Inglaterra busca solo el mercado, no el territorio" y haría todo lo posible por mantenerlo seguro. Los consejeros se esforzaron por demostrar que la medida era justa y necesaria, que hacía mucho tiempo que venía siendo reclamada por los americanos y que era la única manera de conseguir el objetivo de que "España y sus Indias florezcan y compongan de hecho y de derecho una misma monarquía".

13 Memoria de D. Miguel de Lastarria sobre América. Madrid, 26-XII-1818. AGI, Estado, $78, \mathrm{n}^{\circ} 47$ (1). Al respecto puede verse Di Meglio - Rabinovich, 2018: 59-78. Sobre la expedición y sus miembros, Cuño, 2008; Marchena, 1983.

14 En el requerimiento que Pedro Cevallos realizó a Lastarria esperaba que este pudiera "fijar el concepto verdadero de las miras de Portugal que, propasándose de sus límites territoriales, á un tiempo hacía aprestos militares al parecer hostiles y los correspondientes al deseado viaje marítimo desde Rio de Janeiro a Cádiz de S.M. Ntra. Reina y Sra. y de S.A. la serenísima señora infanta, que se dignaron realizar la satisfacción fundamental de la monarquía con sus altos enlaces matrimoniales". Apunte de Papeles de Lastarria. Madrid, 26-XII-1818. AGI, Estado, 78, $\mathrm{n}^{\circ}$ 47 (1a). Los matrimonios se celebrarían finalmente en septiembre de 1816. Ternavasio, 2015: 244.

15 Resolución de la junta de pacificación y consejo reunidos. Madrid, 8-II-1817. AGI, Estado, 88, n 11 (2). 
El objetivo era, por tanto, recuperar los derechos sobre el Río de la Plata con el beneplácito de las potencias europeas que, reunidas en Aquisgrán, discutirían acerca del asunto americano. En este sentido, el secretario de Estado, José García de León y Pizarro, ya había trasladado a Fernando una exposición en la que se concretaba el envío de una expedición militar al Río de la Plata y que incluía, además, otras medidas como la apertura del comercio a los extranjeros y la amnistía a los refugiados ${ }^{16}$. También el embajador en Rusia, Cea Bermúdez, confiaba en que Europa correspondiera, por su propio interés, a conservar la integridad territorial de España, pues consideraba que la disolución de esta pondría en peligro el sistema político entero sobre el que se asentaba el concierto europeo. Sin embargo, a pesar de que los ministros del rey habían preparado esta propuesta para negociar la pacificación de América en el congreso europeo, finalmente la monarquía española no fue invitada a participar de las deliberaciones. La reacción de Fernando no se hizo esperar, rompió las negociaciones diplomáticas con los británicos y dio luz verde a la formación del ejército expedicionario ${ }^{17}$. Esta actitud empeoró, más si cabe, las maltrechas relaciones con los portugueses, que el 20 de enero de 1817 habían ocupado la ciudad de Montevideo y también movían sus agentes diplomáticos en las cortes europeas para obtener el consentimiento de estos actos. Los conflictos territoriales con los portugueses tenían, además, una vertiente peninsular, pues incluían la cuestión de la devolución de Olivenza, ocupada por los españoles durante la guerra de las naranjas.

Así las cosas, la decisión de preparar una expedición para el Río de la Plata fue tomada el 22 de mayo de 1818 después de que los consejeros del rey dictaran resolución sobre el asunto y tras la aprobación de un nuevo opúsculo que Lastarria había escrito sobre la pacificación de América ${ }^{18}$. Aunque la cuestión se perfilaba urgente, la toma de Montevideo por los portugueses entorpecía los planes españoles, pues ya no sería posible desembarcar allí para organizar el ataque a Buenos Aires. Era evidente que Portugal no iba a facilitar ni apoyar el desembarco, e incluso fortificó la capital y la ciudad de Colonia por si debía resistir ataques de las fuerzas expedicionarias. La actitud portuguesa de cerrar la boca del Plata junto a la aparición de la epidemia de fiebre amarilla entre las tropas que se acantonaban en Andalucía, a la espera de ser embarcadas, fueron algunas de las razones por la cuales se demoró el envío de la expedición.

\subsection{Miguel de Lastarria: la fidelidad de un ilustrado}

Miguel de Lastarria volvió a insistir, en diciembre de 1818, al secretario de Estado marqués de Casa Irujo, sobre la urgente necesidad de atender la situación de los territorios del Plata. En lo que ya parecía que se había convertido en casi una obsesión, relató nuevamente los antecedentes de su conducta, describió los trabajos que había recopilado durante años y expuso, una vez más, la importancia del territorio platense

16 Acerca de las actuaciones de Pizarro y de su Memoria sobre la pacificación de América durante estos años véase Delgado, 2006: 5-44. Este autor defiende que la propuesta del ministro suponía el inicio de un proceso descolonizador que garantizara a España un trato preferente con Hispanoamérica.

17 Méndez, 1998; Molina de Muñoz, 1977.

18 Sistema de pacificación de las colonias españolas que en servicio del rey N. S. Presenta debidamente al exmo. Sr primer secretario de Estado y del despacho D. José García de León y Pizarro, el fiscal de la Real Audiencia Pretorial de Buenos Aires D. Miguel de Lastarria, natural de Arequipa en el Perú. El texto fue presentado el 26 de abril de 1817. 
para la monarquía española. Lo interesante de esta memoria es la percepción que Lastarria tenía de que el tiempo se escapaba a su control. En realidad, narraba, casi sin darse cuenta, los vertiginosos cambios del proceso revolucionario que se desató en 1808. Cuando desde Buenos Aires ya se habían configurado los planes para reconquistar los territorios que los portugueses habían ocupado, esperando el envío de cuatro mil hombres al mando del general José Bustamante y Guerra -que con cargo de virrey comandaba la expedición- se produjeron las invasiones inglesas. El nombrado general en jefe tuvo que ceder el puesto a Santiago Liniers quien, como héroe defensor de la ciudad porteña, fue aclamado como virrey. "Todo esto sucedía casi simultánea y rápidamente" al tiempo que se producía la cautividad del rey Fernando y el traslado de la corte de Lisboa a Rio de Janeiro, escribiría Lastarria. Desde su posición privilegiada de funcionario de la administración borbónica y desde la visión regional de la cuenca del Plata, Lastarria refería una aceleración del tiempo histórico que había trastocado en sus fundamentos la existencia misma de la monarquía.

Desde entonces, Lastarria abrazó la causa del Plata como algo personal, convencido como estaba de que el abandono y la pérdida de aquella parte de la monarquía sería la antesala de males venideros. Por ello, dice, "insistí en la expresada mi agencia conducente a la seguridad de aquellos dominios de S. M.", solicitando el envío de una fuerza armada expedicionaria y profesional que pudiera marchar a las lejanas fronteras a recuperar el territorio usurpado por los portugueses. Ya en época de la Junta Central, las reclamaciones de las provincias americanas sobre la ampliación del comercio y la supresión de trabas arancelarias le compelió a proponer un proyecto para activar el intercambio de Buenos Aires con el extranjero, pues estaba seguro que, de no reformarse el que había, "se prostituiría aquel emporio, abrazando equivocadamente las sugestiones insurreccionales que asomaban, cuando el último virrey que expulsaron los rebeldes, se vio precisado a autorizar tan oportuno tráfico marítimo de acuerdo a las autoridades [...] que se reunieron en cabildo que dicen abierto" $"$. Lastarria, como servidor fiel de una administración que representaba el universo de legitimidad en el que se había formado, no concebía otro horizonte que el de la recuperación del territorio y los derechos de Fernando ${ }^{20}$.

Pero en el tiempo presente desde el que hablaba, diciembre de 1818, reconocía que las medidas propuestas en sus proyectos anteriores tal vez no eran las más adecuadas en aquel entonces. Los sucesos acontecidos desde inicios del siglo habían redefinido las alianzas internacionales en un juego cambiante de desconfianza permanente donde la diplomacia derivaba, no en pocas ocasiones, en disimulada guerra $^{21}$. Desde esta atalaya, Lastarria echaba la vista atrás y recomponía su horizonte de experiencias respecto a la seguridad y pacificación de las provincias del Plata. En ese ejercicio retrospectivo e introspectivo a la vez, puede observarse la deriva del arequipeño desde la racionalidad ilustrada hacia posiciones y lenguajes casi rayanos en la reacción. Así, en su consideración, habían existido cuatro estados

19 Memoria de D. Miguel de Lastarria sobre América. Madrid, 26-XII-1818. AGI, Estado 78, no 47 (1), f. 7v. El subrayado es original.

20 Desde la isla de León había dirigido a la segunda regencia un proyecto que sería costeado por comerciantes gaditanos para enviar "una expedición de tres mil hombres para apagar el fuego de la insurrección que empezaba a arder en el Río de la Plata”. Ibídem, f. 6.

21 Un novedoso enfoque sobre el juego diplomático del momento restaurador abordado desde el tiempo presente de sus protagonistas que evita la ilusión retrospectiva en Ternavasio, [en prensa\}. Agradezco a la autora la consulta de este manuscrito. 
por los que había pasado la solución para el mal de la revolución. Un mal que para Lastarria estaba aniquilando moralmente los dominios del monarca legítimo. En el primero de estos momentos - referido a 1810 - cuando se descubrió "el acceso insurreccional de los demagogos que con el terror e hipocresía sobrecogían los ánimos, desbastaban [sic] y trastornaban todo" hubiera bastado que el ejército del Alto Perú descendiese triunfante a prestar la cooperación necesaria en la región oriental del Plata. Más tarde, como los rebeldes no contaban con fuerza moral, en la segunda etapa hubiera resultado útil la mediación británica que, a modo de calmante, hubiera hecho retroceder a estos. Se situaba entonces en torno a 1814. Para Lastarria, la acción conjunta de Gran Bretaña y España habría favorecido a ambas potencias, los británicos hubieran obtenido los beneficios mercantiles que ansiaban y los insurgentes no habrían conseguido la fuerza política que les concedió la apertura de puertos a los extranjeros.

En el tercer estadio de este tiempo histórico trastocado fue cuando se complicaron en gran manera las cosas. Los "innovadores" incrementaron sus fuerzas militares y obtuvieron recursos para sostener la insurrección a costa de las propiedades de "los desgraciados habitantes" de aquella región. Fue entonces, en 1816, cuando escribió sus papeles sobre la pacificación, la cual consideraba que debía ser obra "de la sabiduría escoltada por las armas" de la forma más respetable posible. Llegaba así Lastarria al cuarto estado, al tiempo presente, en el que "la insolencia ha exaltado el furor de los necios insurgentes" siendo ya de extrema necesidad "curarlos con la fuerza como a locos perdidos". Una fuerza que el ilustrado entendía en todos los sentidos: física o militar, política, y moral o filosófica, "según las máximas que inspira nuestra Santa Religión Católica”. Justificaba así el cambio en sus opiniones, la inversión de los términos, pues había llegado el momento en que "no son ya las armas las que han de secundar a la sabiduría, sino esta a aquellas, o que no ya la oliva, sino la espada ha de marchar al frente para servir de emblema de nuestro esfuerzo de pacificación, dirigiendo empero la sabiduría su plan"22. A pesar de todo, insistía en que la racionalidad y no los sentimientos debían acompañar ese plan de pacificación armada.

La posición de Miguel de Lastarria a finales de 1818 será la de un fiel y leal vasallo convencido de la urgencia de restaurar los derechos del rey español en los territorios del Plata y deseoso de que sus escritos sean tenidos en cuenta para diseñar la estrategia de pacificación. Identificado con ese objetivo no dudará en escribir una carta al secretario de Estado, duque de San Fernando, en 1819 para prevenirle sobre los malintencionados que desean hacer fracasar la expedición que se prepara con destino Buenos Aires. Y en este despliegue de lealtad al soberano acusa principalmente a algunos americanos de intrigantes que disimulan su apoyo a la revolución:

[...] el resultado de algunas indagaciones y el conocimiento que tengo del carácter de los Americanos que se hallan por estos países e igualmente de algunos Europeos, me han convencido a creer que la causa de todo nuestro mal actual está en esa Corte donde cabalmente se hallan con brillantes destinos varios americanos y europeos que aparentando ser opuestos a la revolución de ultramar, indirectamente la fomentan, [...] a los cuales puede V.E. sin escrúpulo alguno contar en el número de los muchos enemigos que ha tenido, tiene y tendrá la expedición al Río de la

22 Memoria de D. Miguel de Lastarria sobre América. Madrid, 26-XII-1818. AGI, Estado 78, $\mathrm{n}^{\circ} 47$ (1), f. $16 \mathrm{v}$. 
Plata, y que a no haber cautela con ellos tratarán por cuanto medio les sea posible de entorpecerla por tercera vez ${ }^{23}$.

Con todo, Miguel de Lastarria representa a uno de esos dramatis personae que vivieron en la cambiante y acelerada coyuntura del tránsito de un régimen a otro, de una cultura política a otra, adaptándose al contexto según su intuición racional les dictaba y con un sentido del deber anclado en la lealtad al soberano, fuera este el rey o la nación. Sus actuaciones en este itinerario aunarán sincréticamente lo privado y lo público como parte de una misma dimensión política. Cuando el sistema constitucional sea restaurado en la monarquía española en 1820, Lastarria será elegido diputado suplente por el Perú y, aunque no tuvo un gran protagonismo en las Cortes, dejará algunas intervenciones que muestran esa acomodación, sin pérdida de coherencia, a los nuevos tiempos.

Sus poderes fueron aprobados el 5 de julio de 1820 y formó parte de varias comisiones a lo largo de la primera legislatura. Una de sus primeras intervenciones fue para proponer la adaptación del escudo real y sus formas de representación al sistema constitucional ${ }^{24}$. Con ello, pretendía la construcción de una memoria perpetua que aunara tanto a la nación como al rey. Es decir, Lastarria fusionaba su antigua lealtad al legítimo soberano con la presente asunción de la soberanía nacional. Era capaz de transitar de una fidelidad personal, vivida como una relación directa con el monarca, a una lealtad hacia una entidad abstracta hacia la que, igualmente, le unía un compromiso de obediencia ${ }^{25}$. En su proposición pedía que se le atribuyera al monarca un título propio distintivo de su condición, invocándole como "Fernando el Constitucional". Así, configuraba una nueva identidad que le permitía atraer su anterior lealtad como funcionario del rey hacia su presente fidelidad como ciudadano constitucional. A ello unía también su más ferviente deseo, la unión de todos los territorios de la monarquía y proponía que, en las representaciones del escudo real, en sellos o monedas, sobre la corona se situara una figura de "dos mundos" y sobre ellos un libro con la inscripción "Constitución, fundamento de la felicidad". Además, en cinta separada se debía incluir la leyenda "Constitución política" y, por último, que se empezara a contar en el calendario la era constitucional desde el día 9 de julio, "en que más solemnemente se entiende publicada la Constitución".

En su paso por las Cortes del Trienio Liberal, Miguel de Lastarria no se distinguió como orador en ninguno de los debates trascendentes para los americanos; su trabajo fue más bien silencioso, al interior de las comisiones, aportando sus conocimientos sobre el territorio rioplatense en materia de milicias, misiones, fronteras, hacienda, etc. Sin embargo, cabe destacar que votó conjuntamente con el resto de la mayoría de diputados americanos las proposiciones para establecer un imperio federal en Amé-

23 Y apuntaba: “y en prueba de esta aserción informen con reserva el marqués de la Concordia, Elío y Vigodet sobre algunos individuos que despacharon de la América por fundadas sospechas y hoy día se ven, desgraciadamente, premiados". Carta de Miguel de Lastarria al duque de San Fernando. Madrid, 23-II-1820. AGI, Estado $104, \mathrm{n}^{\circ} 30$.

24 Diario de Sesiones de Cortes (en adelante DSC), 21-VII-1820: 226-227.

25 Ribeiro, 2013, t. I: 32. En Miguel de Lastarria concurrían todos los méritos asociados a la lealtad del funcionario de la administración borbónica en América que ha descrito Ana Ribeiro: perseverancia, coraje para enfrentar riesgos físicos, honestidad en el manejo de bienes públicos, integridad y justificación de su conducta, obediencia, búsqueda de ventajas y exhibición de lealtad. 
rica con infantes borbónicos coronados ${ }^{26}$. Es decir, a diferencia de otros personajes del momento, no parece que Lastarria experimentara un trauma por la dislocación del tiempo histórico en el que le había tocado vivir, sino que acomodaba su juicio en aras de un bien mayor que identificaba con la unidad de la monarquía. Parecía que lo importante era mantener unidos los territorios en una sola lealtad, en una sola soberanía fuera esta, indistintamente, absolutista o constitucional. Solo así se explica que, años después, en 1826, ya anciano y retirado en Sevilla, siguiera esbozando planes de reconquista para recuperar la Banda Oriental, a la que consideraba la llave del Pacífico $^{27}$. Este fue el camino que transitaron muchos de los sujetos del momento cuyas lealtades siempre acompañaron los vaivenes políticos de la época, del absolutismo al liberalismo y vuelta al absolutismo. Ello no significó una contradicción insuperable sino la demostración de una inquebrantable adhesión a una idea de unidad, la de la monarquía, sustentada en la lealtad que pasaba de un cuerpo político a otro.

\section{La política conciliatoria en el Trienio Liberal}

El asunto de la pacificación de América no se detuvo con la revolución que, en 1820 , puso en vigor nuevamente el sistema constitucional. Ahora bien, el cambio de régimen obligó, en cierta manera, a moderar las aspiraciones militaristas y reconducirlas hacia posiciones de apariencia más conciliatoria. Tras ser intimado a jurar la Constitución, Fernando VII actuó rápidamente y dirigió una proclama a los habitantes de Ultramar en la que asentaba la línea oficial del gobierno de la cual no se apartaría durante los tres años que sobrevivió el régimen liberal: la Constitución era el bálsamo reparador que garantizaba los derechos y libertades de América y bajo cuya protección los rebeldes americanos debían deponer las armas y regresar al seno de la monarquía ${ }^{28}$. Inmediatamente se nombraron comisionados que debían viajar a los territorios en guerra para ofrecer una mediación y conseguir la paz ${ }^{29}$ mientras, en paralelo, se reactivaron las negociaciones internacionales con un acercamiento a Gran Bretaña.

El tablero político de la diplomacia europea se movía de nuevo, -en realidad, no había dejado de hacerlo- y el Río de la Plata seguía estando en el centro del mismo ${ }^{30}$. Desde Londres, el duque de San Carlos escribía confidencialmente a su amigo y secretario de Estado, duque de San Fernando, acerca de la importancia de obtener el apoyo británico: "La Inglaterra es la que debemos interesar y solo un tratado de

26 Sobre la propuesta de secciones de Cortes y establecimiento de monarcas Borbones en América ver Benson, 1954; Rodríguez, 1993; Frasquet, 2008: 72 y ss.

27 Mariluz Urquijo, 1958: 165.

28 La junta provisional consultiva que se había formado en marzo hasta que se pudieran reunir las Cortes será un reflejo del nuevo enfoque dado a la política sobre la cuestión americana, pues insistía en que "la pacificación de la América es ya mas una obra de política que de la fuerza y que solo la Constitución puede restablecer los lazos fraternales que la unían con la madre patria”. Carta de Luis de Borbón, cardenal de Scala, arzobispo de Tolego dirigida al secretario de Estado y de la Gobernación de Ultramar. Madrid, 19-IV-1820. AGI, Indiferente 1568, $\mathrm{n}^{\circ} 71$.

29 Los comisionados fueron enviados a Venezuela, Santa Fe, Buenos Aires, Chile y Lima. Sobre la política conciliadora en esta etapa véase Riaza, 2011.

30 Como aseguró el Conde de Casa Flores - a la sazón enviado español a Río de Janeiro- a Juan Jabat, el 5 de junio de 1820, dicho territorio constituía la "Manzana de la Discordia". Documentos para a historia da independencia, 1923: 156. En París había tenido lugar una conferencia para tratar de solucionar la cuestión de la Banda Oriental entre portugueses y españoles. Al respecto véase Sanz, 1983. 
comercio franco y bien entendido, extendiéndolo como no se puede evitar a América [...] puede ser el que nos proporcione su apoyo efectivo" 31 . El embajador se mostraba sincero con su amigo, los ingleses ya realizaban el comercio a sus espaldas, mejor sería legalizarlo para no perder del todo las colonias. Por otro lado, estaba la cuestión de la Banda Oriental. Los portugueses seguían interesados en ella desde que la ocuparon tres años atrás y ya habían ofrecido en varias ocasiones la posibilidad de comprarla. El duque de Palmela, enviado de la corte bragantina en Londres, se había dirigido a San Carlos para reiterarle la oferta de "comprar aquel terreno de la Banda Oriental o con dinero o por otro equivalente en América". A los portugueses no les resultaba fácil justificar la ocupación del territorio oriental ante la diplomacia europea, y aunque insistían constantemente en que era una cuestión de seguridad para evitar la extensión de la revolución, lo cierto es que el tema oriental acabaría siendo motivo de controversia entre los territorios lusos a ambos lados del Atlántico. El diplomático español, en un tono que solo podía ser fruto de la familiaridad y confianza que le tenía a su interlocutor, conjeturaba que podría ser un buen negocio, pues "vendemos lo que no tenemos, y lo que en mi corto entender, es difícil y largo, si no improbable de recobrar" "32. Es evidente que esta afirmación se realizaba fuera de la postura oficial del gobierno de Fernando VII, pero resulta sintomático que ya en marzo de 1820, el embajador español en Londres, considerara la posibilidad de la definitiva pérdida de la Banda Oriental. Es más, San Carlos aseguraba que, por cartas particulares, conocía "que la opinión general está por reformas, y tú sabes el influjo que tiene la opinión".

De este modo, la Banda Oriental, y en concreto Montevideo, cobrarán un inusitado protagonismo en los años del Trienio Liberal, sobre todo en la política internacional, al situarse en el centro de las negociaciones entre Portugal, España y Gran Bretaña y por extensión de Brasil y las Provincias Unidas del Río de la Plata. También, porque en estos cambiantes y convulsos años, aunque breves, los acontecimientos revolucionarios de Oporto primero y de Brasil después, influirán notablemente en el devenir del futuro de esta parte del Plata. En cuanto a las actuaciones de los gabinetes ministeriales y consejeros de Fernando VII, ya he referido cómo la política americana de los gobiernos liberales del Trienio dejaba suspendida en el aire el envío de una expedición militar para concentrarse en medidas conciliatorias que, bajo el auspicio del sistema constitucional, obtuviesen el regreso de los territorios en guerra a la unidad de la monarquía. En ese contexto, resulta interesante analizar la participación de los diputados americanos por el Río de la Plata en las Cortes. Aunque esta no alcanzó el nivel sobresaliente de algunos otros, sí contó con un representante que, desde su posición de portavoz de los americanos leales a la corona, trató de aportar soluciones pactadas al conflicto platense. Se trataba de Francisco de Borja Magariños quien, elegido suplente por la circunscripción de la "provincia de Buenos Aires", tuvo una actuación destacada en lo que se refiere a las propuestas de pacificación de aquel territorio.

Magariños era natural de Montevideo, de familia ligada a la administración colonial y con negocios mercantiles. Su padre, Mateo Magariños, lideró el grupo de

31 Carta del duque de San Carlos al duque de San Fernando. Londres, 8-III-1820. AGI, Estado 104, n 31. Delgado, 2006.

32 Para San Carlos, lo que los portugueses deseaban con la operación era "legalizar aquella posesión por nuestra parte así como lo ha hecho con los insurgentes en el tratado del general Lecor que Palmela niega". Carta del duque de San Carlos al duque de San Fernando. Londres, 8-III-1820. AGI, Estado 104, nº 31. 
exiliados españoles leales a la corona que emigró desde la capital oriental hacia Rio de Janeiro en 1814, tras la ocupación de la primera por las tropas insurgentes. Al parecer, fue en ese momento cuando se le envió a continuar sus estudios en España desde donde asistió a las tramas y vaivenes políticos que afectaron a su región natalicia $^{33}$. Su participación en los negocios públicos se incardinaba en una más amplia red de alianzas comerciales cuya gestión desempeñaba desde Madrid. Francisco mantuvo los contactos con su padre y los emigrados en la corte brasileña quienes, a través de la embajada ejercida por el conde de Casa Flores, le enviaban información de las actuaciones tanto de los portugueses como de los bonaerenses en la Banda Oriental. Entre 1817 y 1820 este grupo de leales a la corona confiaba en el envío de una expedición militar que les devolviera sus propiedades y su influencia en Montevideo. Una esperanza que quedaría frustrada con el triunfo de la revolución liberal en la Península, por ello, a partir de entonces, depositaron en Francisco Magariños sus expectativas de retorno y recuperación de sus tramas de poder en la Banda Oriental ${ }^{34}$.

\section{Lealtad y fidelidad en Francisco de Borja Magariños}

La actividad parlamentaria de Francisco Magariños en las Cortes de Madrid no fue extensa, sin embargo, resulta interesante rastrear su actuación en relación con la situación política de la Banda Oriental y sus intereses en los negocios familiares. En la mayoría de sus intervenciones Magariños apoyó propuestas relativas a las provincias rioplatenses, insistiendo en la atención que estas merecían para salvar la unidad de la monarquía. Aunque al inicio de las sesiones de la primera legislatura trató de rehusar el cargo de diputado porque "perseguido él y toda su familia por su adhesión a la justa causa de la madre Patria, y siendo sus opiniones opuestas a los del país que representaba, ni él podía, ni aquella provincia aceptaría tal representación", la comisión de poderes no aceptó su renuncia y juró su cargo a principios de julio de $1820^{35}$. A los dos días de iniciadas las sesiones, Magariños presentó una indicación para que se decretara una amnistía general para toda la España ultramarina y que las autoridades monárquicas procedieran a poner en libertad inmediatamente a todos los detenidos por motivos de disidencia. La propuesta pasó a la comisión de legislación con el añadido de que se extendiera a todos los individuos que se hallaran presos también en la Península por iguales causas ${ }^{36}$. No será la única vez que Magariños consiga que alguna de sus indicaciones sea aprobada por las Cortes. En el debate sobre la aprobación del reglamento de Milicias nacionales, insistirá en que este debe ser extendido y aplicado - con las adaptaciones pertinentes- a América. Su intervención, apoyada por otros diputados, mostró que en las provincias platenses las milicias se habían formado hacía mucho tiempo, desde que se produjeron las invasiones británicas y,

33 Francisco Magariños nació en 1796, por lo que cuando fue enviado a España debía contar con 18 años de edad. Bonaudo, 2015: 65-69.

34 La actuación de este grupo en estos años ha sido estudiada por Caula, 2002 y 2019; Frega, 2009; no así la participación del diputado Magariños en Madrid a partir de 1820.

35 DSC, 11-VII-1820. Francisco Magariños fue elegido, como el resto de americanos suplentes, en la votación realizada en Madrid el 29 de mayo de 1820. El 5 de julio se aprobaron sus poderes y al día siguiente presentó su exposición de renuncia.

36 No será hasta unos meses después, en septiembre, que se apruebe la amnistía en un debate en el que el montevideano apenas puntualizó que el tiempo de duración de la misma debería fijarlo el gobierno según las noticias que tuviera sobre las provincias americanas. DSC, 17-IX-1820: 1075. 
por lo tanto, era necesario un reglamento que evitara el arbitrio y despotismo de las autoridades en la formación de estos cuerpos. En sus alegatos Magariños siempre reforzaba la idea permanente de la lealtad a la monarquía y la unidad de la nación: "En Montevideo, en Chile, Lima, etc., han sido el baluarte y defensa de los buenos españoles [...] ¿Por qué se les han de negar los auxilios de defensa que se conceden a todo español, a todo hombre libre? ¿No lo son ellos? ¿No pertenecen a esta gran nación?"37 Sin embargo, en otras ocasiones sus indicaciones no fueron tenidas en cuenta por la mayoría de la cámara.

A pesar de ello, cuando la legislatura ya estaba a punto de tocar a su fin, un 25 de octubre tomó la palabra para exponer ante la cámara el estado en el que se encontraban las provincias del Río de la Plata. Magariños había recibido noticias de su padre y del grupo de leales que se encontraba en la corte de Río de Janeiro y presentó un cuadro lastimoso de las desgracias sufridas por Montevideo desde su primera ocupación, así como de la situación en la que estaban "los honrados españoles europeos y americanos [que] se encuentran allí oprimidos, vejados y padeciendo miserias de toda especie" 38 . Por la información recibida sabía que el cambio político en la monarquía "había sido aplaudido por los buenos" pero "no había producido la menor sensación favorable en los espíritus inquietos que promueven el desorden en aquellas abundantes y dilatadas regiones por el prurito de su soñada e inmatura independencia". De alguna manera el diputado revelaba que la estrategia del gobierno de fiarlo todo a los beneficios que la Constitución traería, no estaba funcionando. La crítica más acerada fue contra los portugueses, que habían ocupado el territorio ilegalmente y deseaban "enseñorearse de aquellas provincias, uniéndolas al territorio del Brasil y fundando una dilatada y poderosa monarquía" 39 . La urgencia de la situación reclamaba tomar medidas inmediatas, entre ellas, que los secretarios del despacho de Estado y de Ultramar, se presentaran a las Cortes para dar cuenta de lo que constara oficialmente en el gobierno sobre la ocupación de Montevideo por las tropas portuguesas y de las propuestas para la pacificación de aquellos territorios. Según Magariños, los habitantes de Montevideo y la "parte sana" de los de Buenos Aires, deseaban volver a ver tremolar la bandera nacional, por lo tanto, había que ayudarles a convencer a los disidentes de las ventajas que les proporcionaría unirse al régimen constitucional. También solicitó que se nombrara una comisión especial para examinar las providencias que debían adoptarse tanto "para exigir la devolución de Montevideo como para poner fin a la persecución que sufren los leales españoles sujetos a la fuerza al dominio de una facción y de la dominación extranjera". Estas propuestas muestran cómo el diputado montevideano cimentaba su acción política y actuar público sobre un horizonte de expectativas que gravitaban en torno a intereses particulares y perspectivas de grupo. Todas sus intervenciones revelan el papel que asumió como portavoz político de los leales montevideanos en las Cortes del Trienio $^{40}$. Sus proposiciones fueron aprobadas por las Cortes, pero a pesar de ello,

\footnotetext{
DSC, 23-VIII-1820: 627-628.
}

DSC, 25-X-1820: 1893.

39 Ibídem. Y añadía: "si los portugueses ocupan aquellos países, es con miras conocidamente siniestras, pues que ninguna autorización, ningún tratado les ha dado derecho para su ocupación: a lo menos hasta ahora lo ignoramos".

40 En alguna ocasión afirmó: “yo, en cumplimiento de la obligación que me impone el carácter de representante de los dignos españoles americanos [...] me veo, digo en la precisión de suplicar a las cortes, para lo que haré formal indicación...”. DSC, 30-III-1821: 771. 
nada se actuó en este sentido, ya que meses después Magariños todavía reclamaba la formación de esa comisión especial y la comparecencia de los ministros para informar sobre la ocupación de Montevideo por los portugueses. Era este, sin duda, un tema delicado que mantuvo a Fernando VII y a su gobierno atrapado en la inacción política generada por las relaciones familiares con la corte bragantina y la diplomacia europea.

\subsection{El volcán político de 1821}

En cuanto a la política interna de la monarquía borbónica, 1821 sería el año clave para comprender las posiciones que tomaron el gobierno español, los diputados americanos de unas y otras regiones, y el resto de autoridades peninsulares como el Consejo de Estado y el propio Fernando VII. Como he indicado, la línea oficial del gobierno fue la contención de las soluciones armadas y la confianza en que el restablecimiento de la Constitución funcionaría como medicina curativa de los males insurgentes. Sin embargo, desde finales de 1820 prácticamente toda Sudamérica estaba en guerra y los dos grandes virreinatos de Nueva España y Perú pronto romperían su calma para sumarse a la misma a lo largo de 1821 .

La actuación de Magariños en las Cortes de la segunda legislatura-que comenzó en marzo de 1821- tampoco fue destacada en cuanto al número de intervenciones. Su accionar político se movió más bien en relación directa con el gobierno, enviando cartas a los ministros de Estado y de Ultramar sobre la situación de su provincia y las medidas que consideraba se debían adoptar para conseguir el fin de la guerra y la unión a la monarquía. A finales del primer mes presentó nuevamente el panorama político de las provincias de América del Sur. Había recibido noticias de Lima en donde se detallaban las negociaciones y entrevistas entabladas entre el capitán general del Perú y el ejército disidente. También tenía conocimiento de las actividades hostiles de Cochrane y por ello solicitaba que se activara el asunto del envío de dos fragatas de guerra al puerto del Callao con el que ya había convenido el gobierno ${ }^{41}$. Fue esta la única vez que se escuchó la voz de Magariños en la cámara durante la legislatura.

Resulta llamativo que Magariños no participara en los importantes debates que para obtener mayor autonomía y autogobierno estaban promoviendo los diputados americanos en estas Cortes. Al respecto es conocida la participación señalada de la diputación novohispana en el aumento del número de diputaciones provinciales y en la extensión de la Constitución en aquellos territorios. Aunque pueda parecer obvio, asumiendo que la situación de las provincias rioplatenses era muy distinta a la de los dos grandes ex virreinatos que se mantenían fieles a la monarquía -Nueva España y Perú- cabe cuestionarse por qué quien actuaba como representante de los fieles a la monarquía en la Banda Oriental, no buscó un mayor apoyo político entre sus compañeros americanos en las Cortes. Francisco Magariños no signó el plan que a finales de junio de 1821 la diputación americana presentó para organizar América en tres reinos con infantes Borbones coronados y con una división de los poderes en tres secciones americanas. Una proposición que había sido discutida en las reuniones de la comisión mixta de ultramar con los secretarios de gobierno y que reflejaba lo que por aquel entonces se conocía como "la independencia pactada". El plan conte-

41 DSC, 30-III-1821: 771-773. 
nía una transición hacia un modelo político que, de llevarse a cabo, convertiría a la monarquía española en federal ${ }^{42}$. Si, como no dejaba de repetir, existía en el Río de la Plata un partido que deseaba el restablecimiento del orden y la unidad e integridad de la monarquía, no acaba de entenderse que Francisco Magariños actuara por libre en este asunto. Tal vez se podría apuntar -a modo de hipótesis- que no estimara incluir al Río de la Plata en el plan federal por no ser considerado este territorio como una de las sedes de los gobiernos americanos, recayendo estas en México, Lima y Bogotá. Sin embargo, Magariños pensaba que la suerte del espacio platense estaba ligada con la del Perú y Chile, por ello reclamaba la remisión de las dos fragatas de guerra al Pacífico, con la intención de liberar la capital peruana de la influencia de San Martín y auxiliar a Benavides, quien mantenía la lucha por los derechos de la monarquía española en la región austral. Si esta última se pacificaba, entonces veía probable que "el gobierno de Buenos Aires se muestre más dócil y dispuesto a una transacción amistosa", y en caso de que no, "será muy fácil desde Chile dar nuevo ser y vida al partido de la nación que aún existe en aquellas provincias, por más que quieran decir los insurgentes lo contrario".

Estas consideraciones las exponía Magariños en una carta dirigida al secretario del despacho de Ultramar en julio de 1821, una vez finalizada la legislatura y en el impasse del verano hasta que se retomara la actividad parlamentaria en septiembre ${ }^{43}$. En la misiva se permitía recomendar al gobierno algunos puntos a tener en cuenta respecto al restablecimiento del orden en aquellas provincias. Entre ellos consideraba que debía llegarse a una transacción con los portugueses para la entrega de Montevideo, aun cuando hubiera que realizar algunos sacrificios. Seguramente pensaba en Olivenza, reclamada insistentemente por el gobierno de João VI en las negociaciones internacionales. Pero si algo quedaba claro en el planteamiento del diputado, era que Montevideo se convertía en la llave para la pacificación del resto del Plata. Su recuperación era indispensable si se quería obtener alguna garantía de éxito en este sentido, por ello apuntaba que el deseo de los habitantes orientales era alcanzar la paz, por eso se habían entregado gustosos a los portugueses y señalaba: "mucho más conseguiremos nosotros ocupando a Montevideo y siguiendo una marcha igual liberal y justa". Con ello Magariños evidenciaba los importantes cambios políticos que se habían producido en la monarquía vecina la que, desde la revolución de agosto de 1820 en Oporto, estaba transitando a un régimen constitucional cuya base temporal era la Constitución de 1812. Tal vez pretendía hacer comprender al gobierno español que la promesa de aplicación del sistema constitucional en el territorio platense ya no era garantía suficiente de conseguir la pacificación, en tanto que los portugueses también habían abrazado un régimen liberal y el rey João VI había prometido jurar la Constitución que elaborasen en Portugal las Cortes reunidas en Lisboa ${ }^{44}$. El monarca había regresado de su exilio americano instalándose en la capital portuguesa desde principios de julio de 1821, dejando a su heredero don Pedro como regente de Brasil.

Es en este contexto, en el verano de 1821, en el que la contingencia política a punto estuvo de cambiar la suerte de América y la confluencia de distintos factores podía haber ofrecido soluciones divergentes a la cuestión americana. A principios de

42 Lucas Alamán definía el proyecto como una gran confederación, con el rey de España a su cabeza, "pero bajo la forma representativa" y "sin el nombre de independencia". Citado en Frasquet, 2020: 195.

43 Carta de Francisco Magariños al secretario del despacho de Ultramar, Ramón López Pelegrín. Madrid, 7-VII1821. Archivo General de la Nación del Uruguay [Uruguay] (en adelante AGNU). Caja 108. Carpeta 3.

44 Berbel, 2008: 232. 
junio los diputados mexicanos solicitaron que se diera cuenta en las Cortes de las noticias de la rebelión ocurrida en Nueva España. Entretanto, el embajador británico en Madrid, Lionel Hervey, informaba de la reunión de los enviados de Bolívar con el secretario de Estado para entablar negociaciones sobre la base de la independencia. Por otro lado, de América llegaban noticias desalentadoras, la guerra se había reanudado en Venezuela después de fenecido el armisticio y en la batalla de Carabobo las fuerzas españolas habían sido derrotadas. Mientras, en México, Juan O’Donojú había pactado con Iturbide el reconocimiento de la independencia bajo la entronización de un monarca Borbón. Por si fuera poco, el Perú se incendió tras el fracaso de las conversaciones entre San Martín y La Serna. Y si esto no era suficiente, el ministro portugués, Silvestre Pinheiro Ferreira, confirmaba que João VI, antes de regresar a Lisboa, se había mostrado dispuesto a reconocer la independencia de los territorios circundantes con sus dominios brasileños ${ }^{45}$. Así pues, en cuestión de pocos meses, el volcán americano había entrado en erupción y la guerra se extendía rápidamente arrasándolo todo a su paso.

Fue entonces, a finales de agosto de 1821, cuando Francisco Magariños respondió al cuestionario que el secretario de Ultramar había circulado entre los diputados al inicio de la legislatura. En él se pretendía recabar información sobre los orígenes y las medidas necesarias para calmar la insurrección en América ${ }^{46}$. Su respuesta, calificada como "reservada", no aportaba demasiadas novedades respecto a las indicaciones que ya había realizado Magariños tanto en las Cortes como en sus comunicaciones con el gobierno. De hecho, en ella se desprende cierto tono irónico al confesarse sorprendido por que el gobierno recurriera a la opinión de los diputados rioplatenses tras once años de revolución. La exposición iba acompañada de algunos documentos, como una copia del acta de independencia publicada en Córdoba (Tucumán) el 9 de julio de 1816, un resumen de los sucesos más notables ocurridos hasta el 30 de agosto de 1820, una memoria que el diputado pasó de orden del ministerio de guerra el 30 de agosto de 1819 al capitán general del ejército destinado al Río de la Plata, el conde de Calderón, y una representación con fecha de 26 de abril de 1821 de 78 ciudadanos rioplatenses emigrados a Río de Janeiro ${ }^{47}$. En su exposición, Francisco Magariños se erigía nuevamente en el portavoz de los americanos leales que con tantas dificultades se mantenían fieles a la monarquía en el Río de la Plata. Ya no era tiempo de legaciones diplomáticas ni envío de comisionados, tampoco del uso de la fuerza armada, pues ante esta perspectiva los revolucionarios se habían unido para evitar ser reconquistados. El diputado reconocía que, de hecho, aquellos territorios "están en posesión de su independencia” y que las nuevas generaciones habían crecido en un ambiente político de libertad. Por ello, la solución estaba en aplicar un

45 Respecto a las independencias hispanoamericanas y su relación con Brasil, véase Pimenta, 2017.

46 El cuestionario fue enviado inicialmente por Antonio Porcel a finales de marzo de 1821, su sucesor, Ramón Feliu, reiteró el pedimento a los diputados que todavía no habían contestado, hasta que, finalmente, Ramón López Pelegrín conminó nuevamente a Magariños para que fuera respondido lo antes posible. Pídese a los Diputados en Cortes por las provincias de Ultramar expongan lo que tienen por conveniente sobre el origen de la revolución de América y medios de calmarlas. Palacio (Madrid), 23-III-1821. AGI, Indiferente 1569, n 130. Frasquet, 2010: 128.

47 Respuesta de Francisco Magariños al secretario de Estado y del Despacho de Ultramar. Morata de Tajuña, 28VIII-1821. AGI, Indiferente 1569, doc. $\mathrm{n}^{\mathrm{o}}$ 141. Magariños anota erróneamente que el acta de independencia del 9 de julio tuvo lugar en 1815. La carta era obra del grupo de leales a la corona que su padre, Mateo Magariños, lideraba en su exilio en Rio de Janeiro. En ella se solicitaba el envío de fuerza armada a la Banda Oriental para recuperar el territorio. Ribeiro, 2013, t. II: 268-270. 
verdadero liberalismo, abriendo el comercio, la industria y ampliando la educación $\mathrm{y}$, sobre todo, cuidando de que se ejerciese una auténtica igualdad de derechos. Todo esto debía conseguirse "sin intentar en manera alguna hostilizar a los independientes", sino que la fuerza armada que se enviase debía únicamente cumplir una función de refugio para proteger a aquellos que desearan unirse a la madre patria.

Este proyecto necesitaba de la desocupación de Montevideo por parte de los portugueses para convertir esta capital en centro logístico y de recursos. Junto a él adjuntaba un plan escrito por su padre en el que se designaban las personas dispuestas a llevar a cabo esta empresa y puntualizaba: "así pues es preciso que inmediatamente se forme un campo de asilo que sea la cuna de un nuevo imperio". Como ha indicado Ana Ribeiro, se trataba de construir una nueva territorialidad española cuyo centro sería la Banda Oriental, respetando, a su vez, el estatus político y territorial conquistado por la revolución. Magariños orientaba perfectamente su opinión hacia la configuración de una posición jurídica para Montevideo que se diferenciara tanto del gobierno de las Provincias Unidas del Río de la Plata, a las que ya reconocía su independencia, como del reino de Brasil, considerado como "un país absolutamente desconocido y extranjero para los españoles". España debía brindar algo diferente a los leales orientales que estaban rodeados por dos nuevas potencias en vías de consolidación y que podían igualmente ofrecerles propuestas liberales y constitucionales.

Lo que se desprende de esta exposición, además de la sugerente idea de formar un nuevo imperio en la zona del Plata con centro en la Banda Oriental, es una profunda convicción acerca de los principios del liberalismo político. Magariños proponía que se debían escuchar todas las propuestas que plantearan los rioplatenses sin alarmarse, aunque en ellas se exigiera inmediatamente el reconocimiento de la independencia. España debía convencerles de que no tenía "interés alguno en oprimir la América y conservarla bajo las leyes coloniales", porque estas "están en oposición directa a las luces del siglo, y aquel torrente de doctrinas forman un cuerpo tan sólido como necesario de admitir precisamente gobiernos representativos, y que así, cualesquiera que sea la manera bajo que se constituyan los pueblos independientes, la forma representativa es una misma". Incluso, se atrevía a dejar abierta la puerta a la república cuando admitía que "es muy insignificante que la primera persona del estado se establezca en una familia hereditaria, o en cualquiera otra persona electiva con nombre de Rey, Presidente o Director" ${ }^{48}$. Finalmente, el diputado repetía lo que ya le había indicado al ministro en su carta de principios de julio sobre la necesidad de enviar apoyo naval al Pacífico y la recuperación perentoria de la plaza de Montevideo.

Pero todavía no habían terminado las sorpresas para Fernando VII en relación con la ocupación portuguesa de la Banda Oriental. En esos días finales del verano de 1821 debieron llegar las noticias de la celebración del congreso cisplatino en julio en Montevideo. El congreso había sido convocado a instancias del ministro portugués Silvestre Pinheiro Ferreira para conceder a los orientales la decisión sobre su futuro, con el convencimiento de que optarían por la independencia ${ }^{49}$. Sin embargo, el capitán general Frederico Lecor, autoridad brasileña en la Banda Oriental, promovió la incorporación del territorio como provincia integrada al reino de Brasil. Así,

48 Respuesta de Francisco Magariños al secretario de Estado y del Despacho de Ultramar. Morata de Tajuña, 28VIII-1821. AGI, Indiferente 1569, doc. $\mathrm{n}^{\circ} 141$.

49 En él se debía optar por tres posibilidades: incorporarse como provincia al Reino Unido de Portugal, Brasil y Algarves, integrarse en algún otro gobierno vecino - como las Provincias Unidas del Río de la Plata- o constituirse como estado independiente. Martínez Renau, 2018: 91-92. Pimenta, 2002. 
la disputa entre portugueses, bonaerenses y españoles por Montevideo se extendió también a los brasileños, generando un conflicto interno en la monarquía bragantina que culminaría al año siguiente con la proclamación de independencia de Brasil y la declaración de guerra entre ambos estados lusitanos. La actuación díscola de Lecor había desbaratado los planes conciliadores del ministro portugués que, desde hacía unos meses, trabajaba por recomponer las relaciones diplomáticas con la monarquía española, prometiendo el desalojo de la plaza oriental y acomodando acuerdos político-económicos con el Río de la Plata.

Aunque las comunicaciones oficiales entre la monarquía española y la portuguesa sobre el asunto de la incorporación de la provincia cisplatina a Brasil tuvieron lugar a principios de diciembre de 1821, ya en octubre Francisco Magariños conocía la noticia y protestaba sobre la cuestión en carta al secretario de Ultramar. En ella denunciaba que Lecor había amenazado a los montevideanos con retirar las tropas y abandonarlos a su suerte si optaban por la independencia, en cambio, les había ofrecido protección en caso de sancionar la incorporación al Brasil. Este punto, reclamado por el gobierno español, era desmentido por Manuel de Castro Pereira -encargado de negocios de Portugal en Madrid- a pesar de que Pinheiro Ferreira había prometido la retirada de los Voluntarios Reales y el desalojo de la plaza ${ }^{50}$. Cabe recordar que lo que realmente se aprobó en el congreso cisplatino no fue la integración como provincia al Brasil, sino la incorporación directa al Reino Unido como un territorio más, con el mismo estatus jurídico que el resto de reinos. Eso apunta hacia la idea de federación del imperio portugués a tan solo un mes de que los diputados mexicanos la hubieran planteado en las Cortes para el caso español. Sin embargo, como indica Martínez Renau, a un lado y otro del océano, la incorporación de la Cisplatina fue entendida como la unión al Brasil, lo que generó no pocas desavenencias entre la corte de Lisboa y la de Madrid ${ }^{51}$.

Para Magariños, el resultado del congreso era "nulo y de ningún valor, porque todo él es obra de una facción patrocinada por las armas portuguesas". Esta opinión la trasladaba en un escrito al presidente de las Cortes de la legislatura que acababa de comenzar en febrero de 1822. El diputado explicaba las difíciles circunstancias en las que los leales de Montevideo se habían reunido de forma reservada para realizar la elección de su diputado a las Cortes. Relataba en su carta cómo el grupo de españoles de Río de Janeiro y los vecinos de la villa del Cerro Largo, habían procedido a nombrarle como su representante para la legislatura de 1822-1823 y solicitaba que se admitieran sus poderes a pesar de que el proceso electoral no se había ajustado del todo a lo requerido en la fórmula constitucional: "ellos [los poderes] no son conformes a la constitución, pero sí son de mucho valor y de mucha estima en el modo con que han sido dados y en las circunstancias en que se encuentra aquel país" ${ }^{52}$. Sin embargo, a pesar de su insistencia, las Cortes no resolvieron sobre la legalidad de la elección de Francisco Magariños para esta legislatura, la cual seguía reclamando en carta de octubre de 1822.

50 Frega, 2009: 31 .

51 La actuación de Lecor también supuso graves desencuentros con el ministro portugués. Sobre esta cuestión véase Martínez Renau, 2020. La misma idea sugiere Sánchez, 2009.

52 Magariños apelaba a la relajación de los formalismos en las circunstancias en las que se hallaba Montevideo, porque al fin y al cabo lo importante es que reunía "la voluntad general de la provincia". Carta de Francisco Magariños al presidente de las Cortes. Madrid, 26-II-1822. AGNU, caja 108, carpeta 3. 


\subsection{El desenlace (con)federal}

Una de las últimas comunicaciones de Francisco Magariños con el gobierno español del Trienio se produjo en abril de 1822. Se trata de una extensa carta en la que el montevideano afina su interpretación sobre la posible solución para la Banda Oriental, adaptando su opinión al devenir cambiante de la revolución y advirtiendo que resultaba indispensable adoptar un "nuevo conducto en el sistema actual de la política". Sin ambages admitía que "la emancipación a que marchan con rapidez las provincias de Ultramar es una inclinación que se ha hecho ya muy difícil de amortiguar" 53 . La misiva rezuma cierta aflicción por lo que pudo ser y no fue, por las oportunidades perdidas, por no haber sido escuchado. La independencia de Brasil -que ya consideraba declarada a pesar de la fecha- complicaba más si cabe la relación de la monarquía española con la portuguesa, pues por identidad de ideas y principios, la antigua colonia y la metrópoli defenderían intereses conjuntos. Esta nueva situación destruía cualquier negociación que pudiera darse sobre la devolución de Montevideo y colocaba a los leales españoles "en el triste caso de tener que abandonarlo todo".

Sin embargo, cuando parecería de Magariños había renunciado en su idea de recuperar el control de la región oriental del Plata, presentó una última propuesta que ofrece sentido y coherencia a la posición de quien llevaba dos años planteando soluciones y ajustando sus expectativas a las incertidumbres de un proceso revolucionario dilatado en el tiempo y en la distancia. En la carta retomaba la idea de coronar infantes de la casa de Borbón en América considerando que había llegado el caso de erigir "un grande imperio que se divida en España y en América" para finalizar de una vez por todas la guerra fratricida que devoraba aquellos territorios. Utilizando la metáfora de la familia en la que se le hace caso al padre, Magariños vaticinaba que, con el establecimiento de un imperio federal, una sería la nación, no por dominio, sino por costumbres y parentesco, por compartir la religión y el idioma que eran fuertes vínculos difíciles de mudar. Esta opinión la ejemplificaba con la existencia del gobierno de los Estados Unidos, "en donde cada estado es independiente y unido por ciertas atribuciones que han delegado, o más bien se han desprendido a favor de la unidad, para mantener en vigor y fuerza el poder supremo ejecutivo". Sin duda el diputado era conocedor de las ideas que circulaban por el espacio euroatlántico sobre la solución confederal de la experiencia norteamericana e insistía en que la política podía ofrecer arreglos adecuados según las inclinaciones de cada país ${ }^{54}$. Tal vez coronar infantes era una salida satisfactoria para Nueva España y el Perú, pues según Magariños, allí las cosas no se habían llevado al extremo, sino que se habían conservado el territorio y los recursos. Pero en el Río de la Plata la balcanización territorial había desintegrado la posibilidad de mantener unido el antiguo espacio geográfico que ahora se hallaba fragmentado en distintos gobiernos provinciales autoproclamados como repúblicas independientes: "Buenos Aires se cree rebajada por la invasión de los pueblos del interior, y estos no pueden sufrir la superioridad de la antigua capital y disputándose con las armas la igualdad, están resueltos a mantener su inde-

\footnotetext{
53 Carta de Francisco Magariños al secretario del despacho de Ultramar. Madrid, 19-IV-1822. AGNU, caja 108, carpeta 3 .

54 Al respecto de la comparación con la experiencia norteamericana en el espacio rioplatense véase el trabajo de Marcela Ternavasio en este dossier.
} 
pendencia territorial". Ahí no existía vínculo de unión ninguno, nada tenía que ver esa situación con la de los ex virreinatos novohispano y peruano. El montevideano explicitaba la dificultad de aplicar los mismos remedios en los diversos territorios americanos, algo que la política de pacificación de la monarquía española no había llegado a comprender ni durante la restauración absolutista ni en el trienio liberal.

Por estas razones, nueva y peculiar, es decir, adaptada a las circunstancias, debía ser la política para la región. Magariños auguraba que el interés de Buenos Aires por Montevideo sería retomado cuando consiguiera controlar la inestabilidad interior, gobernada como estaba por un sujeto de talento "pero de genio fuerte e intolerante", refiriéndose a Rivadavia. Si España quería seguir manteniendo lazos de unión con aquellas provincias debía enviar comisionados y, una vez cesadas las hostilidades, entablar lazos de amistad, abrir las puertas del comercio con la península y tratar en las Cortes de la felicidad de ambos mundos "concediéndoles si necesario fuere el principio de admitir la independencia". Tal vez no se explique muy bien esta posición de Magariños si no se comprende que, siendo fiel a sus principios de lealtad a la monarquía, auspiciaba soluciones que, a la altura de 1822, solo podían pasar por el reconocimiento de la independencia, pero enmarcada en una suerte de gobierno (con)federal. No sería aventurado afirmar que Magariños conocía las discusiones entre americanos y peninsulares que se tuvieron a finales de la legislatura extraordinaria, en febrero de 1822, a pesar de no haberse sentado en la cámara como diputado. En ellas se sancionó la nulidad de los tratados de Córdoba que O’Donojú había firmado en México con Iturbide y se decidió el envío de comisionados para entablar negociaciones pacíficas. Fue durante estas sesiones que el diputado Francisco Golfín presentó como alternativa una memoria escrita por Miguel Cabrera de Nevares en la que se diseñaba una solución confederal para la monarquía hispánica ${ }^{55}$. Era una solución perfecta para un leal como Magariños. Independencia y monarquía fusionadas en una misma propuesta, la salvación para Montevideo a la que podían avenirse los gobiernos rioplatenses porque Rivadavia había dicho "que es preciso tratar con España y que es inevitable entenderse con ella". Vana esperanza que, como se sabe, nunca llegó a materializarse.

\section{A modo de conclusión}

Una de las cosas que puede sorprender al analizar las trayectorias vitales de algunos personajes que atravesaron el espacio atlántico en el período de las revoluciones de independencia, es la aparente relativa facilidad con la que mutaban sus convicciones políticas. Por ello, ha sido habitual considerar estas actuaciones como deshonestas, oportunistas y faltas de coherencia. Sin embargo, un estudio más detallado de los márgenes de actuación, que valore la contingencia y sitúe las decisiones en el contexto histórico adecuado, revela la adaptación a un proceso político que se caracterizó por las indefiniciones e incertidumbres permanentes. Los ejemplos de Miguel de Lastarria y Francisco Magariños evidencian la congruencia de su accionar político si se considera la lealtad como el eje vertebrador de sus decisiones.

55 El proyecto reconocía, en su primer artículo, la independencia de aquellas provincias donde ya se hallaba establecida de hecho y regulaba las relaciones entre estas y la península en base a una igualdad recíproca, libertades comerciales y, por supuesto, una paz duradera. 
Fernando VII nunca contempló, ni remotamente, la posibilidad de conceder el más mínimo indicio de autogobierno a los americanos, lo cual no sorprende de un rey depredador como fue él. Desde esta perspectiva, resulta comprensible que los planes de recuperación de América durante la primera restauración pasaran, de manera irrenunciable, por mantener la territorialidad construida durante el período colonial. La unidad de la monarquía era un principio inquebrantable, al que el monarca siempre asoció el ejercicio del poder absoluto, por esa razón no pudo consentir, si quiera, una remodelación de las prácticas de comercio.

Sin embargo, otra cosa sería la oportunidad perdida durante el régimen constitucional por unos liberales que, aun reconociendo justa la causa, fueron incapaces de conceder a los americanos lo que deseaban para la España peninsular. La política del trienio respecto a América siempre trató a todos los territorios por igual, sin hacer distinciones entre ellos, sin ver diferencias entre México o Buenos Aires y, por lo tanto, incapaz de ofrecer soluciones adaptadas a las diversas situaciones que la revolución provocó en cada región. Esa circunstancia complicó sobremanera que los americanos pudieran auspiciar soluciones conjuntas para sus territorios en unas Cortes que, con todo su liberalismo, seguían concibiendo el imperio como una unidad sometida a las decisiones peninsulares.

En este caso, Lastarria y Magariños fueron adaptando sus propuestas a los vaivenes de la situación política. Si, por un lado, el primero mostró una convicción más firme a la recuperación del territorio por la fuerza y la imposición absoluta de la lealtad a la corona -solo en el breve impasse del Trienio consideraría ambiguamente la legitimidad de la soberanía nacional- como buen representante ilustrado de la monarquía que era; por otro, el segundo, cuya juventud transcurrió en España durante el momento liberal, se adaptaría mejor a una lealtad que transitaba entre el sostenimiento del vínculo simbólico con la monarquía y el reconocimiento de la independencia del Plata. En cualquier caso, sus experiencias y actuaciones políticas son solo dos ejemplos de la complejidad variable y la inestabilidad perenne que caracterizó los años de la revolución.

\section{Referencias bibliográficas}

Benson, Nettie Lee, La diputación provincial y el federalismo mexicano. México: El Colegio de México, 1955.

Berbel, Marcia Regina. "A Constituição espanhola no mundo luso-americano (1820-1823)". Revista de Indias, vol. LXVIII, nº 242 (2008), 225-254.

Bonaudo, Marta. "Francisco de Magariños: un americano tensionado entre la fidelidad a la monarquía y la construcción de una nueva república". Secuencia, n 92 , mayo-agosto (2015), 61-82.

Cabrera de Nevares, Miguel, Memoria sobre el estado actual de las Américas y medio de pacificarlas escrita de orden del Excmo. Sr. D. Ramón López Pelegrín, secretario de Estado y del Despacho de la Gobernación de Ultramar, y presentada a S.M. y a las Cortes extraordinarias por el ciudadano Miguel Cabrera de Nevares. Madrid: Imprenta de don José del Collado, 1821.

Cáceres Riquelme, Jorge. "Si la razón es verdadera, ¿para qué sirven el ejemplo y la autoridad?" Ilustración y conciencia crítica en dos textos del criollo Miguel de Lastarria". Revista de Crítica Literaria Latinoamericana, vol. 88 (2018), 389-404. 
Caula, Elsa. "Negocios y estrategias de una red mercantil a comienzo del siglo XIX". Cuadernos de Trabajo. Buenos Aires: Universidad Argentina de la Empresa, 2002.

- "Diplomacia y política. La legación española en Río de Janeiro ante la invasión portuguesa a la Provincia Oriental (1817-1820)". Mélanges de la Casa de Velázquez, nº 49, vol. 2 , (2019), 271-291.

Cuño, Justo, El retorno del Rey: El restablecimiento del régimen colonial en Cartagena de Indias (1815-1821). Castellón: UJI, 2008.

Delgado, Josep Maria. "La desintegración del imperio español. Un caso de descolonización frustrada (1797-1837). Illes i Imperis, $\mathrm{n}^{\circ}$ 8, (2006), 5-44.

Di Meglio, Gabriel - Rabinovich, Alejandro Martín. "La sombra de la Restauración. Amenazas militares y giros políticos durante la revolución en el Río de la Plata, 1814-1815". Revista Universitaria de Historia Militar, vol. 7, nº 15 (2018), pp. 59-78.

Documentos para a historia da independencia, vol. I. Rio de Janeiro: Officinas Graphicas da Bibliotheca Nacional, 1923.

Donoso, Ricardo. “En torno a la personalidad de Don Miguel Lastarria, 1759-1827”. Revista de Historia de América, no 46 (Dic., 1958), 427-464.

Frasquet, Ivana. Las caras del águila. Del liberalismo gaditano a la República federal mexicana, 1820-1824. Castellón: UJI, 2008.

— "La segunda oportunidad. La "pacificación de las Américas" en el contexto constitucional de 1820. El caso de México”. En La construcción del estado y la nación en España y México, editado por Suárez Cortina, Manuel - Pérez Vejo, Tomás. Santander: Biblioteca Nueva - Universidad de Cantabria, 2010, 118-140.

— "México en el Trienio Liberal. Entre la autonomía monárquica y la federación imposible". En La revolución politica. Entre autonomías e independencias hispanoamericanas, editado por Frasquet, Ivana - Peralta, Víctor. Madrid: Marcial Pons, 2020, 189-214.

Frega, Ana. "Alianzas y proyectos independentistas en los inicios del «Estado Cisplatino»". En Historia regional e independencia del Uruguay, coordinado por Frega, Ana. Montevideo: Ediciones de la Banda Oriental, 2009, 19-63.

Jauss, Hans Robert. Experiencia estética y hermenéutica literaria. Madrid: Taurus, 1986.

Koselleck, Reinhart. Futuro Pasado. Para una semántica de los tiempos históricos. Buenos Aires: Paidós, 1993.

La Parra, Emilio. Fernando VII. Un rey deseado y detestado. Barcelona: Tusquets, 2018.

Marchena Fernández, Juan. Oficiales y soldados en el ejército de América. Sevilla: EEHA, 1983.

Mariluz Urquijo, José María. Los proyectos españoles para reconquistar el Río de la Plata (1820-1833). Buenos Aires: Ed. Perrot, 1958.

Martínez Martín, Carmen. "El ilustrado criollo Miguel de Lastarria en las Cortes de Cádiz". En La Constitución gaditana de 1812 y sus repercusiones en América, vol. 1, coordinado por Gullón Abao, Alberto José - Gutiérrez Escudero, Antonio. Cádiz: Universidad de Cádiz, 2012, 439-458.

Martínez Renau, Laura. "Gobernar la Cisplatina. Montevideo entre la monarquía portuguesa y el imperio del Brasil (1820-1824). En Tiempo de política, tiempo de Constitución. La monarquía hispánica entre la revolución y la reacción (1780-1840), coordinado por Frasquet, Ivana - García Monerris, Encarna. Granada: Comares, 2018, 87-110.

- "¿Independencia o unión? Proyectos políticos para la Banda Oriental: el Congreso Cisplatino de 1821". En El tribunal de la soberanía. El poder legislativo en la conformación de los estados: América Latina, siglo XIX, coordinado por Irurozqui Victoriano, Marta. Madrid: Marcial Pons, 2020, 23-47. 
Martínez Riaza, Ascensión. “«Para reintegrar la Nación». El Perú en la política negociadora del Trienio Liberal con los disidentes americanos, 1820-1824”. Revista de Indias, vol. LXXI, n 253 (2011), 647-692.

Méndez Salcedo, Ildefonso. "La pacificación de Hispanoamérica. Una relación cronológica y temática, 1810-1828”. En Ensayos de interpretación histórica e historiográfica. Caracas: Biblioteca de Autores y Temas Tachirenses, 1998, 121-161.

Molina de Muñoz, Stella Maris. "Política ultramarina de Fernando VII". Revista de Historia Militar, $\mathrm{n}^{\circ}$ 41, (1976), 42-67.

— "La expedición pacificadora al Río de la Plata". Revista de Historia Militar, n 42, (1977), $52-77$.

Pimenta, João Paulo G. Estado e nação no fim dos impérios ibéricos no Prata (1808-1828). Sao Paulo: Hucitec, 2002.

- La independencia de Brasil y la experiencia hispanoamericana (1808-1822). Santiago de Chile: Centro de investigaciones Diego Barros Arana, 2017.

Riberio, Ana. Los muy fieles. Leales a la corona en el proceso revolucionario rioplatense. Montevideo/Asunción, 1810-1820, t. I y II. Montevideo: Planeta, 2013.

Rodríguez O., Jaime E. “La transición de colonia a nación: Nueva España, 1820-1821”. Historia Mexicana, vol. XLIII, no 2 (1993), 265-322.

Sánchez Gómez, Julio. "Brasil y Uruguay: dos procesos de independencia íntimamente relacionados”. En Las independencias iberoamericanas ¿un proceso imaginado?, coordinado por Bosco Amores, Juan. Bilbao: Universidad del País Vasco, 2009, 139-182.

Sanz, Víctor. "La conferencia de París sobre la Banda Oriental: 1817-1819”. Boletín Americanista, no 33 (1983), 119-142.

Ternavasio, Marcela. Candidata a la corona. La infanta Carlota Joaquina en el laberinto de las revoluciones hispanoamericanas, Buenos Aires: Siglo XXI, 2015.

- Las independencias hispanoamericanas en suspenso. Una historia en tiempo presente [en prensa].

Torrente, Mariano. Historia de la revolución hispano-americana, t. III. Madrid: Imprenta de Moreno, 1830. 
